\title{
Answering questions of Information Access Dialogue (IAD) task using ellipsis handling of follow-up questions
}

\author{
Junichi Fukumoto \\ Department of Media Technology \\ Ritsumeikan University \\ 1-1-1 Nojihigashi, Kusatsu, Shiga 525-8577 Japan \\ fukumoto@media.ritsumei.ac.jp
}

\begin{abstract}
In this paper, we propose ellipsis handling method for follow-up questions in Information Access Dialogue (IAD) task of NTCIR QAC3. In this method, our system classifies ellipsis patterns of question sentences into three types and recognizes elliptical elements using ellipsis handling algorithm for each type. In the evaluation using Formal Run and Reference Run data, there were several cases which our algorithm could not handle ellipsis correctly. According to the analysis of evaluation results, the main reason of low performance was lack of word information for recognition of referential elements. If our system can recognize word meanings correctly, some errors will not occur and ellipsis handling works well.
\end{abstract}

\section{Introduction}

In question answering task QAC of NTCIR (Kato et al., 2005)(Kato et al., 2004), interactive use of question answering is proposed as one of evaluation task called Information Access Dialogue (IAD) task, which was called subtask3 in QAC1,2. In IAD task, a set of question consists of one first question and several follow-up questions. These series of questions and answers comprise an information access dialogue. In QAC1, there was only one follow-up question in a series of questions, but in QAC2 and 3 there were several follow-up questions.
All follow-up questions have anaphoric expressions including zero anaphora which is frequently occurs in Japanese. There were several approaches to answer follow-up questions. One approach was to extract answers of follow-up questions from documents which were retrieved using clue words of the first question (Sasaki et al., 2002). In the other approach, they added clue words extracted from the previous questions to clue words of follow-up question for document retrieval (Murata et al., 2002). However, when topic was changed in a series of questions, these approaches did not work well because clue words of the previous questions were not always effective to extract answer of the current question.

Our approach is to handle ellipses of follow-up questions and apply the processed questions to ordinary question answering system which extracts answers of a question (Fukumoto et al., 2002)(Fukumoto et al., 2004)(Matsuda and Fukumoto, 2005). For QAC3, we have improved our previous approach to handle follow-up questions, that is, we have expanded ellipsis handling rules more precisely. Based on the analysis of evaluation results of QAC2, we have classified ellipsis pattern of question sentences into three types. The first type is ellipsis using pronoun. This is the case that a word used in previous questions is replaced with pronoun. The second type is ellipsis of word in verb's obligatory case elements in the follow-up question. Some obligatory case elements of a verb of a follow-up question will be omitted and such elements also used in the previous question. The last type is ellipsis of a modifier or modificand in a follow-up question. Such an ele- 
ment appears in the previous question and has modification relationship with some word in the followup question sentence. In order to handle the above three ellipsis types, we utilized case information of main verb of a question and co-occurrence of nouns to recognize which case information is omitted. We used co-occurrence dictionary which was developed by Japan Electric Dictionary Research Inc. (EDR) (EDR, ).

As for core QA system which is our main question answering system, we have integrated previous systems modules which are developed for QAC2. One module is to handle numeric type questions. It analyzes co-occurrence data of unit expression and their object names and detects an appropriate numeric type. Another module uses detailed classification of Named Entity for non numerical type questions such as person name, organization name and so on to extract an answer element of a given question.

In the following sections, we will show the details of analysis of elliptical question sentences and our new method of ellipsis handling. We will also discuss our system evaluation on ellipsis handling.

\section{Ellipsis handling}

In this section, we explain what kinds of ellipsis patterns exist in the follow-up questions of a series of questions and how to resolve each ellipsis to apply them to core QA system.

\subsection{Ellipsis in questions}

We have analyzed 319 questions (46sets) which were used in subtask3 of QAC1 and QAC2 and then, classified ellipsis patterns into 3 types as follows:

\section{Replacing with pronoun}

In this pattern, pronoun is used in a follow-up question and this pronoun refers an element or answer of the previous question.

Ex1-1 アメリカの大統領は誰ですか。 (Who is the president of America?)

Ex1-2 そこが独立したのはいつですか。 (When did it become independent?)

In the above example, pronoun “そこ (it)" of question Ex1-2 refers a word “アメリカ (America)" of question Ex1-1. The question Ex1-2 should be “ アメリカが独立したのはいつですか。(When does
America become independent?)" in a completed form.

Ex2-1 アメリカの大統領は誰ですか。 (Who is the president of America?)

Ex2-2 彼の出身地はどこですか。

(Where is his birth place?)

In the above example, pronoun “彼 (his)" of question Ex2-2 refers an answer word “ブッシュ (J. Bush)" of question Ex2-1. The question Ex2-2 should be “ブッシュの出身地はどこですか。(Where is J. Bush's birth place?)" in a completed form.

\section{Ellipsis of an obligatory case element of verb}

In this pattern, an obligatory case element verb in follow-up question is omitted, and the omitted element refers an element or answer of the previous question. An example of this pattern is as follows:

Ex3-1 アメリカの大統領は誰ですか。

(Who is the president of America?)

Ex3-2いつ就任しましたか。

(When did $\phi$ inaugurate?)

In the above example, the verb “就任する (inaugurate)" has two obligatory case frames "agent" and "goal", and the elements of each case frame are omitted. The element of "agent" is the answer of Ex3-1, and the element of "goal" is “大統領 (the President)" of Ex3-1. Therefore, Ex3-2 should be “(the answer of Ex3-1) はいつ大統領に就任しまし たか。(When did (the answer of Ex3-1) inaugurated as the President?)".

\section{Ellipsis of a modifier or modificand}

This pattern is the case of ellipsis of modifier. When there is modification relation between two words of a question, either of them (modifying element or the modified element) modifies an element of the next question but is omitted. We call the modifying element modifier and we call the modified element modificand. The following example shows ellipsis of modifier.

Ex4-1 アメリカの大統領は誰ですか。

(Who is the president of America?)

Ex4-2 国務長官は誰ですか。

(Who is a minister of state?)

In the above example, the word “アメリカ (America)" is modifier of “大統領 (the president)" in the question Ex4-1. Then, the word “アメリカ (America)” also modifies “国務長官 (a minister of state)” 
of Ex4-2 and is also omitted. The question Ex4-2 should be “アメリカの国務長官は誰ですか。(Who is a minister of state of America?)".

The following example shows ellipsis of modificand.

Ex5-1 アメリカの大統領は誰ですか。 (Who is the president of America?)

Ex5-2 フランスは誰ですか。

(Who is $\phi$ of France?)

In this example, the word “大統領 (the president)" is modificand of the word “アメリカ (America)" in the question Ex5-1. In the question Ex5-2, the word “フランス (France)" should modifies the word “大 統領 (the president)" which is omitted in the question Ex5-2. Then the question Ex5-2 should be " ランスの大統領は誰ですか。(Who is the president of France?)".

\subsection{How to resolve ellipsis}

\subsubsection{Overview of the method}

We will show ellipsis resolution method of these three patterns. For the first pattern, we replace the pronoun with a word which referred by it. For the second pattern, we try to fill up obligatory case frames of the verb. For the third pattern, we take a word from the previous question based on cooccurrence frequency. We assumed that the antecedent of an elliptical question exists in a question which appears just before, so the "previous question" indicates immediately previous question in our method. We show the process as follows:

Step1 Estimate the pattern of ellipsis:

When a follow-up question has pronoun, this is the case of the first pattern. When a follow-up question has some verb which has an omitted case element, this is the case of the second pattern. When a follow-up question has no pronoun and such a verb, this is the case of the third pattern.

Step2 Estimate kinds of the omitted word:

Step2a When the ellipsis pattern is the first pattern:

Estimate the kind of word which the pronoun refers. When the pronoun directly indicates kinds of word (ex: 技: he), depend on it. If the pronoun does not directly indicate kinds of word (ex: その:its +noun), use the kind of the word which exists just behind the pronoun.

Step2b When the ellipsis pattern is the second pattern:

Estimate obligatory case frame of the verb of the follow-up question. Then, estimate omitted element of the case frame and the type of the element.

Step2c When the ellipsis pattern is the third pattern:

Get a noun $X$ which appears with Japanese particle “は (ha)"1 in the follow-up question. When compound noun appears with “は (ha)”, the last word is assumed to be X. Then, collect words which are modifier or modificand of $\mathrm{X}$ from corpus. If the same word as collected words is in the previous question, take over the word and skip step3. Otherwise, estimate the kind of word which is suitable to modifier (or modificand) of X. Estimate the kind of collected modifiers and modificands, and adopt one which has the highest frequency.

Step3 Decide the succeeded word of the previous question:

Estimate type of answer of previous question ${ }^{2}$ and kind of each word used in previous question from rear to front. When a word has a kind fit for the estimate in step2, take the word to follow-up question.

\subsubsection{EDR thesauruses dictionary}

We have used thesauruses of EDR dictionary to estimate the kind of words, obligatory case frame of verbs, omitted element of case frame, and to collect modifier and modificand of a word. Details are as follows:

\section{Estimation of word type}

We used EDR Japanese Word Dictionary and EDR Concept Dictionary. Japanese Word Dictionary records Japanese words and its detailed concept as Concept Code, and Concept Dictionary records each Concept Code and its upper concept. We check a target word using Japanese Word Dictionary and

\footnotetext{
${ }^{1}$ This particle is used as topic marker in Japanese.

${ }^{2}$ Use core QA's module
} 
get its detailed concept code. Then, we generalize type of the word using concept code of Concept Dictionary.

For example, concept code of a word “会社 (company)" is $3 c e 735$ which means "a group of people combined together for business or trade". We will check its upper concept using Concept Dictionary, for example, upper concept of 3ce 735 is $4449 f 5$, upper concept of $4449 f 5$ is $30 f 74 c$, and so on. Finally, we can get word type of $3 c e 735$ as $3 a a 912$ which means "agent (self-functioning entity)". Therefore, we can estimate that type of word “会社 (company)" is an agent.

\section{Estimation of obligatory case frame of verb and omitted element}

We will use EDR Japanese Cooccurrence Dictionary for estimation of omitted case element. Japanese Cooccurrence Dictionary contains information of verb case frame and concept code with Japanese particle for each case. We will check obligatory case frame and omitted element. Firstly, we check a verb with Japanese Cooccurrence Dictionary and get its case frame, concept code and particle information. Then we can recognize omitted case element by particle information and estimate word type of omitted element.

For example, according to the Japanese Cooccurrence Dictionary, a verb “就任する (inaugurate)" has two case frames, agent (30f6bo) and goal (3f98cb or $3 a a 938$ ), and agent is used with particle " が (ga)", goal is used with particle "に (ni)". If question doesn't have any “が (ga)” or “に (ni)” (ex: “い つ就任しましたか。(When did $\phi$ inaugurate?)”), we estimate that agent and goal are omitted. Then, we estimate kind of the omitted element same as "Estimation of kind of words".

\section{Collection of modifier and modificand}

Japanese Cooccurrence Dictionary contains Japanese co-occurrence data of various modifications. We will use the co-occurrence data to collect modifier or modificand of word X. Details as follows:

1. Search "X の (no) noun (noun of $X$ )" and "noun の (no) X (X of noun)" pattern from Japanese Cooccurrence Dictionary
2. When $Y$ appears in the "Y の (no) $X(X$ of $Y)$ " pattern, we can estimate $\mathrm{Y}$ as modifier of $\mathrm{X}$.

3. When $\mathrm{Y}$ appears in the " $\mathrm{X}$ の (no) $\mathrm{Y}$ ( $\mathrm{Y}$ of $\mathrm{X}$ )" pattern, we can estimate $\mathrm{Y}$ as modificand of $\mathrm{X}$.

\subsubsection{Examples of ellipsis handling}

We will show above examples of ellipsis handling in the following.

\section{Example of ellipsis handling of first pattern ${ }^{3}$}

Ex1-1 アメリカの大統領は誰ですか。 (Who is the president of America?)

Ex1-2 そこが独立したのはいつですか。 (When did it become independent?)

Ex1-2’アメリカが独立したのはいつですか。 (When did America become independent?)

In the above example, Ex1-2 has a pronoun “そこ (it)", so we classified ellipsis pattern of Ex1-2 into the first pattern. Pronoun “そこ (it)" refers organization or location by information of pronoun. The word “アメリカ (America)" has information of location but the word “大統領 (the president)" are not organization or location. Then we can estimate that pronoun “そこ (it)" of Ex1-2 refers the word “アメ リカ (America)" of Ex1-1. Question Ex1-2 should be “アメリカの大統領は誰ですか。(Who is the president of America?)".

\section{Example of ellipsis handling of second pattern}

Ex3-1 アメリカの大統領は誰ですか。 (Who is the president of America?)

Ex3-2いつ就任しましたか。 (When did he inaugurated?)

Ex3-2) (answer of Ex3-1) はいつ大統領に 就任しましたか。

(When did (answer of Ex3-1) inaugurated?)

In the above example, Ex3-2 has a verb “就任す る (inaugurate)", so we classified ellipsis pattern of Ex3-2 into the second pattern. The word “就任す る (inaugurate)" has two obligatory case: agent (human) and goal (managerial position). Ex3-2 doesn't have word which is suitable for obligatory cases of " 就任する (inaugurate)”. Therefore we estimate that the agent and the goal are omitted. Then, we estimate answer type of Ex3-1 and kind of each word of Ex3-1. The answer type of Ex3-1 is human, so it

\footnotetext{
${ }^{3} \mathbf{E x m}-\mathbf{n}$ ' indicates complemented question of Exm-n
} 
is suitable for the agent. The kind of “大統領 (the president)" is managerial position, so it is suitable for the goal. Finally, we take the answer of Ex31 and “大統領 (the president)" to Ex3-2 and Ex3-2 becomes “(answer of Ex3-1) はいつ大統領に就任 しましたか。(When did (answer of Ex3-1) inaugurated?)".

\section{Example of ellipsis handling of third pattern}

Ex4-1 アメリカの大統領は誰ですか。 (Who is the president of America?)

Ex4-2 国務長官は誰ですか。 (Who is a minister of state?)

Ex4-2' アメリカの国務長官は誰ですか。 (Who is a minister of state of America?)

In the above example, Ex4-2 doesn't have any pronoun and verb, so we classified ellipsis pattern of Ex4-2 into the third pattern. Then we search "noun の国務長官 (a minister of noun)” and “国務長官の noun (noun of a minister)" pattern from the Japanese Cooccurrence Dictionary. In the Japanese Cooccurrence Dictionary, we can find “アメリカの国務長官 (a minister of America)" pattern. “アメリカ (America)" is used in Ex4-1, so we take over “アメリカ (America)" to Ex4-2 and Ex4-2 becomes “アメリ カの国務長官は誰ですか。 (Who is a minister of state of America?)".

\section{Evaluation}

\subsection{Evaluation method}

We have evaluated our QA system only on ellipses handling. The following example shows question sets of the Formal Run and Reference Run. In Qm$\mathbf{n}, \mathrm{m}$ and $\mathrm{n}$ indicates series ID and its question number which we gave and Rm-n indicates a question which correspond to Qm-n.

\section{Questions of Formal Run}

Q1-1 富士山レーダーはいつ設置されましたか。 (When was Mt.Fuji radar installed?)

(QAC3-30038-01)

Q1-2 どういう目的で設置されましたか。 (What kind of purpose was it installed by?)

(QAC3-30038-02)

Q1-3 富士山の何処にありましたか。

(Which area of Mt.Fuji was it installed?)

(QAC3-30038-03)

Q1-4 どのような表彰を受けましたか。

(What kind of award did it get?)

(QAC3-30038-04)

\section{Questions of Reference Run}

R1-1 富士山レーダーはいつ設置されましたか。 (When was Mt.Fuji radar installed?)

(QAC3-31267-01)

R1-2 富士山レーダーはどういう目的で設置さ れましたか。(What kind of purpose was

Mt.Fuji radar installed by?)

(QAC3-31268-01)

R1-3 富士山レーダーは富士山の何処にありま したか。(Which area of Mt.Fuji was Mt.

Fuji radar installed?)

(QAC3-31269-01)

R1-4 富士山レーダーはどのような表彰を受け ましたか。(What kind of award did Mt.

Fuji radar get?)

(QAC3-31270-01)

In IAD task, one series of questions consists of the first question and several follow-up questions which contain ellipsis. In our current implementation, we assumed that antecedent of an elliptical question exists in its just before question. For example, the antecedent of Q1-2 is “富士山レーダー (Mt.Fuji radar)” of Q1-1. The antecedent of Q1-4 is “富士 山レーダー (Mt.Fuji radar)" of Q1-1 actually, however, if Q1-3 is completed correctly (as R1-3), “富士 山レーダー (Mt.Fuji radar)” exists in Q1-3. Therefore, we prepared evaluation data from QAC test set, 310 pairs of questions. One pair consists of a question of Reference Run and a question of Formal Run. For example, R1-1 and Q1-2 is one pair of the evaluation data, R1-3 and Q1-4 is other one. We have evaluated our method using this data. Correctness has been judged by human. When the system must take an answer of previous question, we have used 
" $<$ ANS $>$ " which indicates the answer of previous question. ${ }^{4}$

\subsection{Results}

Our system could complete 52 of 310 questions correctly as results. 28 among 52 success cases are done by ellipsis handling method proposed in the previous QAC evaluation. Our previous approach is based on topic presentation in question sentences. If there is an ellipsis in a question, we will use information of topic information in the previous question. Topic presentation is detected by Japanese particle “ は (ha)". The other cases of 24 were succeeded by the approach described above. We will show the details as follows:

- Replacing with pronoun:

System classified 88 of 310 questions in this pattern. The all of 88 classifications were correct. 12 of 88 questions were completed correctly.

- Ellipsis of an obligatory case element of verb:

System classified 158 of 310 questions as this pattern. 105 of 158 classifications were correct. 8 of 105 questions were completed correctly.

- Ellipsis of a modifier or modificand:

System classified 64 of 310 questions as this pattern. 44 of 64 classifications were correct. 4 of 44 questions were completed correctly.

Major failure cases and their numbers which are indicated with dots are as follows:

\section{Failure of classification of ellipsis pattern}

- System uses wrong verbs...29

- All obligatory cases of verb is filled and other element is omitted...22

- Failure of morphological analysis...8

- An adjective phrase is omitted...1

\footnotetext{
${ }^{4}$ In the Formal Run, we have replace " $<$ ANS $>$ " with the 1st answer of core QA. In the evaluation, considering core QA's failure, we have left " $<$ ANS $>$ " and considered as correct.
}

\section{Failure of estimation of omitted element of follow-up question}

- Verb isn't recorded in Japanese Cooccurrence Dictionary...35

- Shortage of rules for pronoun...17

- System fills up to case already filled up...15

- Any modifier or modificand doesn't exist in Japanese Cooccurrence Dictionary...10

- Case frame element is omitted but system fails to find it...7

- Verb is passive voice...6

- System fails to select the element of modification relation...6

- Question doesn't have element of case frame and it is unnecessary...2

\section{Failure of decision of which word should be taken}

- System fails to estimate word type of answer in the previous question...79

- System fails to decide to scope of target word...21

- A modifier or modificand which has lower cooccurrence frequency should be taken...7

- System takes inappropriate word from an interrogative phrase...6

- Answer type of the previous question has same kind with a word should be taken...3

\section{Discussion}

Our system could work well for some elliptical questions as described in the previous section. We will show some examples and detail of major failure analysis results in the following.

1. Verb case elements:

There was a Japanese delexical verb “いる” in a follow-up question, then our system could not

\footnotetext{
${ }^{5}$ Delexical verb is a functional verb which has specific meaning in it.
} 
fill up its obligatory cases because every obligatory cases of this verb had already filled up. It is necessary to handle these delexical verbs such as “いる”, “なる”, “いう” and so on as stop words.

Otherwise, there were several questions in which all obligatory cases of verb has already filled up. In this case, it is necessary to apply the other approach. In the example “ オープン初日のフィルムカット式に出席し た俳優は誰でしたか。(What is the actor's name who attended opening event in the first day?)", some additional information for "opening event" is omitted. Moreover, there were some verbs which had no case information in EDR dictionary. It would be helpful to check co-occurrence with this word in the previous question.

2. Morphological analysis failure:

The expression “そこで (sokode)" in question sentence was recognized as one conjunction " そこで (then)" although it should be analyzed in “そこ (soko: there)” + “で (de: at)". If morphological analyzer works well, our algorithm could handle ellipsis correctly.

\section{Lack of rules for pronoun:}

In the expression “この宇宙ステーション (this space station)" of question sentence, ellipsis handling rule for pronoun “この (this)" was not implemented, then our method could not handle this case. It is necessary to expand our algorithm for this case.

4. case information handling error:

q1 阿川佐和子がキャスターをしていた のはどこのテレビ局ですか。(Which

TV station is Ms. Sawako Agawa working as TV caster?) (QAC3-31206-01)

q2 初めて書いた長編小説は何ですか。 (What is the title of long novel which $\phi$ firstly wrote?) (QAC3-30029-05)

In the above example ( $q 1$ is the first question and $\mathrm{q} 2$ is follow-up question), system checks obligatory case elements of verb “書 $<$ (write)" of question q1. The verb “書く” has three obligatory cases: agent, object and goal according to EDR dictionary. System estimated that every obligatory case element were omitted, and checks “阿川佐和子 (Ms. Sawako Agawa)”, “キャスター (TV caster)”, “キャス ター (TV caster)" respectively. However, object case of verb “書く” was “長編小説 (long novel)" of question q2 actually. In this question, this element was modified by verb “書 $<$ (write)", then system failed to estimate that the object was already filled. So, our algorithm tried to fill this object case up as “キャスター (TV caster)". It is necessary to improve patterns of estimation of omitted case element.

5. lack of co-occurrence information:

q3 日光東照宮の例大祭は毎年いつ行わ れるのですか。(When is Reitaisai of Nikko Toshogu held in every year?) (QAC3-31235-01)

q4 ハイライトは何ですか。(What is the highlight?)(QAC3-30033-06)

q4' 日光東照宮のハイライトは何ですか。 (What is the highlight of Nikko Toshogu?)

In the above example, $\mathrm{q} 3$ is the first question and $\mathrm{q} 4$ is the follow-up question. The question q4 is replaced with q4' using ellipsis handling. In this case, system took wrong modifier “日光東照宮 (Nikko Toshogu)” for “八 イライト (highlight)”. It is caused by lack of co-occurrence information in EDR Japanese Cooccurrence Dictionary because these words are proper nouns which are not frequently used. In order to handle such cases, it is necessary to use co-occurrence information using large corpus.

\section{Passive verb expression:}

In our current implementation, our system has no rule to handle passive verb. In case of passive voice, it is necessary to check other case element for ellipsis handling.

7. Multiple candidates: 
コリン・パウエルは誰に国務長官に

指名されたのですか。(Who appointed

Mr. Collin Powell as a minister of state?)

(QAC3-31087-01)

q6 彼の政治的な立場はどのようなもの

ですか。(What is his political situation?)

(QAC3-30013-03)

q6'<ANS>の政治的な立場はどのよう

なものですか。(What is <ANS >'s

political situation?)

In the above example, q5 is the first question and q6 is the follow-up question. The question q6 is replaced with q6' using ellipsis handling rules. System replaced “彼 (his)" of q6 with the answer of q5. Because “佊 (his)” refers human and the answer type of q5 is human, and the answer of q5 was the nearest word which suitable to “行 (his)”. But, “彼 (his)” referred “コリン・ パウエル (Mr. Colin Powell)" actually. In this case, “コリン・パウエル (Mr. Colin Powell)" was the topic of q5, so “コリン・パウエル (Mr. Colin Powell)" would be better one than the answer of q5. Topic information handling would be implemented in our algorithm.

\section{Conclusion}

In this paper, we have presented ellipsis handling method for follow-up questions in IAD task. We have classified ellipsis pattern of question sentences into three types and proposed ellipsis handling algorithm for each type. In the evaluation using Formal Run and Reference Run data, there were several cases which our algorithm could not handle ellipsis correctly. According to the analysis of evaluation results, the main reason of low performance was lack of word information for recognition of referential elements. If our system can recognize word meanings correctly, some errors will not occur and ellipsis handling works well.

We have already improved our ellipsis handling method with recognition of target question. In the evaluation of QAC3, our system searches elliptical element in the previous question. However, we have not tested this new algorithm using test correction. In the future work, we will test this algorithm and apply it for other QA application.

\section{References}

EDR Home Page

. http://www2.nict.go.jp/kk/e416/EDR/J_index.html.

Junichi Fukumoto, Tetsuya Endo, and Tatsuhiro Niwa. 2002. Rits-QA: Ritsumeikan question answering system used for QAC-1. In Working Notes of the 3rd NTCIR Workshop Meeting: Part IV QACl, pages 113116. National Institute of Informatics.

Junichi Fukumoto, Tatsuhiro Niwa, Makoto Itoigawa, and Megumi Matsuda. 2004. Rits-QA: List answer detection and context task with ellipsis handling. In Working Notes of the 4th NTCIR Workshop Meeting, pages 310-314. National Institute of Informatics.

Tsuneaki Kato, Junichi Fukumoto, and Fumito Masui. 2004. Question answering challenge for information access dialogue - overview of NTCIR-4 QAC2 subtask 3. In Proceesings of the 5th NTCIR Workshop Meeting on Evaluation of Information Access Technologies, pages 291-297. National Institute of Informatics.

Tsuneaki Kato, Junichi Fukumoto, and Fumito Masui. 2005. An overview of NTCIR-5 QAC3. In Proceesings of the 5th NTCIR Workshop Meeting on Evaluation of Information Access Technologies, pages 361-372. National Institute of Informatics.

Megumi Matsuda and Junichi Fukumoto. 2005. Answering questions of IAD task using reference resolution of follow-up questions. In Proceesings of the 5th NTCIR Workshop Meeting on Evaluation of Information Access Technologies, pages 414-421. National Institute of Informatics.

Masaki Murata, Masao Utiyama, and Hitoshi Isahara. 2002. A question-answering system using unit estimation and probabilistic near-terms ir. In Working Notes of NTCIR Workshop 3 Meeting QAC1, pages 47-54. National Institute of Informatics.

Yutaka Sasaki, Hideki Isozaki, Tsutomu Hirao, Koji Kokuryou, and Eisaku Maeda. 2002. NTT's QA systems for NTCIR QAC-1. In Working Notes of NTCIR Workshop 3 Meeting QACl, pages 63-70. National Institute of Informatics. 